\title{
Currículos de História e expectativas de aprendizagem para os anos finais do ensino fundamental no Brasil (2007-2012)
}

\author{
Curriculum of History and learning expectations for \\ the final years of primary education in Brazil (2007-2012)
}

Margarida Oliveira*

Itamar Freitas ${ }^{\star *}$

\section{RESUMO}

$\mathrm{O}$ artigo traça um perfil das propostas curriculares produzidas entre 2007 e 2011, por 18 estados da Federação, destinadas aos anos finais do ensino fundamental. O texto é um dos resultados da pesquisa empreendida nos últimos três anos por pesquisadores das universidades federais do Rio Grande do Norte e de Sergipe, que prioriza o exame das expectativas de aprendizagem histórica em termos de finalidades, quantidades, distribuição, habilidades, conhecimentos e níveis de incorporação da pesquisa de ponta. O objetivo é fornecer subsídios para o conhecimento e a discussão sobre políticas públicas e apontar a oportunidade de investigação de temáticas e problemas ainda pouco explorados pela academia.

Palavras-chave: ensino de história; currículo; ensino fundamental.

\section{Abstract}

The article presents a profile of curricular proposals produced between 2007 and 2011 by 18 states of Brazil, for the final years of primary education. The text is one of the results of a research undertaken in the last three years by researchers at the federal universities of Rio Grande do Norte and Sergipe, which prioritizes the review of learning expectations in terms of historical purposes, amounts, distribution, skills, knowledge and levels of incorporation of cutting edge research. The goal is to provide subsidies for knowledge and discussion of public policy and point out the opportunity to research issues and problems few explored by the academy.

Keywords: History Teaching, Curriculum, Elementary school.

\footnotetext{
* Departamento de História, Centro de Ciências Humanas, Letras e Artes, Universidade Federal do Rio Grande do Norte (UFRN). Campus Universitário de Lagoa Nova. 59078-970 Natal - RN - Brasil. margaridahistoria@yahoo.com.br

** Centro de Educação e Ciências Humanas, Departamento de Educação, Universidade Federal de Sergipe (UFS). Cidade Universitária "Prof. José Aloísio de Campos". Av. Marechal Rondon, s/n, Jardim Rosa Elze. 49100-000 São Cristóvão - SE - Brasil. itamarfo@gmail.com
} 
Há 14 anos, Circe Bittencourt publicou um balanço das propostas curriculares de história produzidas entre o fim da década de 1980 e o início da de 1990 em 22 estados brasileiros. A intenção da pesquisadora era "identificar o alcance de tais propostas no que se refere às mudanças do conhecimento histórico escolar", ${ }^{1}$ transformações essas operadas a partir do processo de democratização pelo qual passara o país, que resultou até mesmo no retorno da disciplina História aos currículos do ensino fundamental.

Em seu balanço, como o próprio título sugeria, Bittencourt apontou continuidades e transformações. Entre as primeiras, destacou a presença do ensino de história fundado no 'tempo cronológico como único ordenador das mudanças' e do 'estruturalismo' na versão dos 'modos de produção' - com a consequente subsunção do indivíduo à coletividade. Das mudanças, destacou o esforço de algumas propostas para estabelecer uma 'história problema', os cuidados com a análise das noções de tempo histórico, a introdução, ainda que tímida, de estudos sobre as 'culturas africanas' e a superação da ideia de 'espaço europeu' como 'lugar do nascimento da nação' - formação fundada na mistura de raças e no predomínio da experiência portuguesa.

A quase uma década e meia da publicação desse importante inventário, vivenciamos o debate em torno da elaboração e circulação dos Parâmetros Curriculares Nacionais, a produção das Diretrizes Curriculares para o Ensino Médio, a ampliação do Ensino Fundamental em mais um ano e o atendimento de várias demandas sociais que resultaram em prescrições sobre a legislação de ensino, a exemplo das orientações sobre o estudo da história da África e dos afrodescendentes, para citarmos apenas os temas de maior difusão entre os professores do Ensino Básico.

Em termos historiográficos, os novos objetos, problemas e abordagens introduzidos no ambiente acadêmico, no final da década de 1980, parecem conviver civilizadamente com as perspectivas um pouco mais à esquerda. Empregando as categorias de Ciro Flamarion Cardoso, ${ }^{2}$ diríamos: os paradigmas rivais - o 'iluminista' e o 'pós-moderno' -, enfim, reconheceram os seus exageros (e as possibilidades de interação).

Acerca das ideias de aprendizagem, ensino e currículo, vigoram as mesmas certezas cunhadas a partir da obra de autores como Jean Piaget, Lev Semenovich Vygotsky, Jerome Bruner, David Ausubel, Philippe Perrenoud, César Coll e de um grupo de teóricos críticos entre os quais podem ser incluí- 
dos os nomes de Paulo Freire e de Dermeval Saviani. Tais ideias são por demais conhecidas da maioria dos profissionais: desenvolvimento humano em termos de estágios, respeito aos saberes prévios, aluno como construtor de conhecimento, professor como mediador das situações de aprendizagem, pedagogia das competências e dialogismo.

Novidade mesmo, afirmaríamos, foi o crescimento da produção acadêmica resultante da pesquisa básica sobre o ensino de história. Encontros nacionais, revistas, consolidação de grupos de investigação e formação de mestres e doutores proporcionaram o acúmulo de grande experiência analítica (embora de forma desequilibrada) sobre os aspectos que envolvem a aprendizagem histórica em todas as etapas do ensino básico e até do nível superior. Quais os desdobramentos dessa nova conjuntura para a formatação das propostas curriculares elaboradas nos estados do Brasil no período 2007-2012? Que desafios detectados no final da década de 1980 foram superados e que novos problemas se busca enfrentar? Qual o perfil das expectativas de aprendizagem formuladas na última década para os anos finais do ensino fundamental - ambiente privilegiado de formação de pré-adolescentes e adolescentes onde atua o profissional com formação inicial em história?

Este artigo retoma a discussão por nós levantada nos últimos três anos ${ }^{3}$ no sentido de produzir indicadores sobre a experiência brasileira em termos de ensino de história, visando subsidiar políticas públicas, bem como chamar a atenção dos pesquisadores para a importância do investimento na investigação sobre determinadas temáticas e problemas que fogem aos interesses de tal ou tal estado, corrente historiográfica, pedagógica, ou seja, que refletem sobre o ensino de história em escala nacional, frente a outros movimentos e experiências internacionais.

Nos trabalhos de 2011, examinamos as prescrições de pesquisadores de vários países sobre o ensino de história como também as expectativas de aprendizagem produzidas para os anos iniciais do ensino fundamental, no âmbito de 12 capitais brasileiras. Aqui, dando continuidade à pesquisa, analisamos as propostas curriculares produzidas para os anos finais do ensino fundamental, entre os anos 2007 e 2012, em 18 estados da Federação. ${ }^{4}$ Nosso objetivo é esclarecer alguns pontos que consideramos fundamentais para o conhecimento da realidade brasileira em termos de prescrições sobre o ensino de história. Os indicadores que se seguem fornecem, portanto, a estrutura deste artigo: 1. o 
lugar da história na formação do aluno (ou ideal de aluno a ser formado); 2. o sentido de conteúdo e a quantidade de expectativas anunciadas; 3 . as prescrições em termos de conhecimentos e de habilidades (conhecimentos substantivos e meta-históricos); e 4. os usos dos diálogos entre as durações, e dos jogos de escala.

\section{O LUGAR DA HISTÓRIA NA FORMAÇÃO DO ALUNO}

As propostas curriculares para o ensino de história datam da década de 2000, como já informamos. As 18 com as quais trabalhamos ${ }^{5}$ foram elaboradas entre 2007 e 2012, demonstrando a concentração, nesse período, das reformas curriculares estaduais, em grande parte estimuladas pela ampliação do ensino fundamental de nove anos, como também pela ascensão de partidos de centro-esquerda ao poder nos estados, a partir do segundo mandato do presidente Luiz Inácio Lula da Silva.

Do ponto de vista das concepções de história que norteiam as propostas, podemos afirmar que a tônica, diferentemente do que imaginávamos, é a indefinição ou, pelo menos, a não explicitação desse ou daquele paradigma, corrente ou escola. Dois terços das propostas não indicam orientação. Traçam panorama da historiografia europeia do século XX, criticam a 'história positivista', mas, ao contrário das propostas da década de 1980, não fundam as escolhas sobre um ou outro autor.

Mesmo entre os projetos que partem de uma definição de ciência histórica, as afirmações são gerais. Há referências aos historiadores Eric Hobsbawm - a defesa do exame da relação presente-passado-futuro -, Marc Bloch - a história como fornecedora de prazer - e Jörn Rüsen - o estudo das formas de superação das carências humanas. A história também é definida metaforicamente, a exemplo de termos como 'espelhos do tempo' e 'expressão de humanidade'.

Apesar de anunciadas em algumas propostas, as definições não chegam (solitariamente) a determinar a escolha de habilidades, a seleção e a distribuição dos conhecimentos. Isso ocorre por um motivo óbvio, embora pouco compreendido: nenhum historiador/corrente fornece o suporte necessário a todas as demandas do ensino. Observemos, por exemplo, a proposta do estado do Paraná. Ela está centrada na 'perspectiva da formação da consciência histórica', 
devedora da nova história social alemã, que tem Rüsen como figura de proa. No entanto, para a eleição dos 'conteúdos estruturantes' (relações de trabalho, relações de poder e relações culturais), os autores das expectativas reivindicam a contribuição de Eric Hobsbawm e Edward Thompson (trabalho), Norberto Bobbio e Michel Foucault (poder), Raymond Williams, Roger Chartier e Carlo Ginzburg (cultura).

No que se refere às funções da disciplina escolar História, a situação se inverte, uma vez que a maioria explicita essa informação fundamental para os professores, sobretudo. Mesmo na ausência de explicitação da ideia de história-ciência, a maioria das propostas converge para quatro grandes finalidades: a formação de identidades, a capacitação para a cidadania, a leitura crítica da realidade e a compreensão dos procedimentos meta-históricos.

Assim, uma verdadeira vulgata, interligando identidade, cidadania, leitura da realidade e operação historiográfica, se instaura nas propostas. A formação da identidade surge como aquisição das noções e compreensão das identidades individuais/pessoais e coletivas (locais, nacionais, por exemplo). A identidade também aparece na forma de sentimento de pertença, compreensão de si e dos outros, e de percepção da condição do aluno como sujeito histórico. Identidade oscila entre fundamentos e abordagens políticas, antropológicas e historiográficas, mas que convergem para a ideia de formação cidadã.

A cidadania é requerida em termos de conhecimento dos princípios, compreensão e preparação para a ação (atuação). É também traduzida como luta contra a exclusão social e em favor dos direitos fundamentais. Cidadania faz par com a preparação do aluno para a vida em regime democrático, o desenvolvimento da habilidade de fazer escolhas, agir e intervir no mundo que o cerca. Aqui surge o terceiro e mais referido objetivo para o ensino de história: a habilidade de ler o real.

A leitura da realidade, anunciada como leitura do mundo que cerca o aluno, do presente ou da sociedade, atribui à disciplina escolar História a responsabilidade de desenvolver no/com o aluno as habilidades de observar, interpretar, compreender e pensar.

O domínio dos conteúdos meta-históricos, por fim, complementa o leque de finalidades expresso pela vulgata histórica. As justificativas implícitas, aqui, parecem oscilar entre as orientações da psicologia do desenvolvimento - a habilidade de identificar semelhanças e diferenças, continuidades e permanên- 
cias - e as prescrições da teoria/metodologia da história: identificar mudanças e permanências, semelhanças e diferenças, relacionar presente/passado, raciocinar, pensar historicamente, construir consciência histórica ou, simplesmente, conhecer os princípios da ciência da história.

\section{O SENTIDO DE CONTEÚdo E QUANTIDADE DE EXPECTATIVAS ANUNCIADAS}

O que os adolescentes devem aprender com o ensino de história? Essa questão é respondida com o emprego da expressão 'expectativas de aprendizagem'. Não obstante a variedade de concepções de 'aprendizagem', a locução não deixa dúvidas sobre o sentido que queremos transmitir: o que os legisladores, gestores e professores esperam que os alunos aprendam sob a rubrica de uma área do conhecimento chamada história.

Nas propostas, evidentemente, a diversidade de nomenclatura impera. As expectativas são chamadas de 'aprendizagens básicas esperadas' (AL), 'expectativas de aprendizagem' (PR), 'expectativas de ensino e aprendizagem' (GO), 'atitudes' (AM), 'habilidades' (ES, MG, SE, TO), 'capacidades' (MT, SP), 'competências e habilidades' (MS, RS), 'conteúdos' (CE), 'conteúdos, habilidades e competências' (RJ) e 'objetivos' ( $\mathrm{AC}, \mathrm{BA}, \mathrm{PB}, \mathrm{PE}$ ). Como vemos, o glossário indica a incorporação da vulgata construtivista e o quase abandono do vocábulo 'objetivo', associado, no senso comum da docência, ao tecnicismo comportamentalista.

Para nós, entretanto, o anúncio de uma expectativa de aprendizagem ganha a forma de um objetivo educacional, independentemente dos sentidos de ensino e de aprendizagem que se queiram emprestar. Dizendo de outro modo, informar sobre o que se espera que o aluno aprenda requer a construção de uma sentença composta por verbo(s) e substantivo(s) que expressem, simultaneamente, processos cognitivos (lembrar, compreender, aplicar, avaliar, criar, entre outros) e conhecimentos (factuais, conceituais, procedimentais, metacognitivos, entre outros). ${ }^{6}$

Nesse sentido, excetuando-se as propostas do Ceará e de São Paulo ${ }^{7}$, todos os documentos analisados anunciam expectativas em forma de objetivo educacional - alguns mais extensos, contendo dois, três ou mais verbos, outros 
resumidos (veremos isso adiante) -, constatação que nos leva a questionar de início com quantos objetivos se faz uma proposta curricular.

Aqui, novamente, a variação é a tônica. Há estados que prescrevem entre duas e cinco dezenas de objetivos (AC, AL, BA, CE, ES, MT, PR, RS, SE, SP), que estabelecem de seis a nove dezenas objetivos (AM, MG, MS, PB, RJ), e um terceiro grupo que lista entre dezoito e dezenove dezenas de objetivos educacionais (GO, PE, TO). Embora não possamos discutir neste artigo as razões de cada uma dessas escolhas, ${ }^{8}$ podemos inferir que tais números fornecem indícios sobre a pluralidade de concepções acerca de 'conteúdo histórico' (mais ou menos factuais, conceituais ou generalistas) e, ainda, sobre graus diferenciados de autonomia docente e/ou de apoio teórico-metodológico fornecido pelas equipes técnicas.

A forma de distribuição das expectativas por ano ${ }^{9}$ também indica variação. Há propostas que estabelecem a mesma quantidade de objetivos para os dois primeiros ou os dois últimos anos, para os três primeiros ou os três últimos anos do ensino fundamental. Rara é a proposta que os distribui equitativamente. No geral, o $7^{\circ}$ e o $9^{\circ}$ anos recebem o maior número de objetivos. Esses dados nos levam à conclusão de que, em termos de quantidade de objetivos, as propostas não sugerem qualquer tipo de progressão da aprendizagem.

Gráfico 1 - Distribuição das expectativas entre os anos finais do ensino fundamental e por estado (2007-2011)

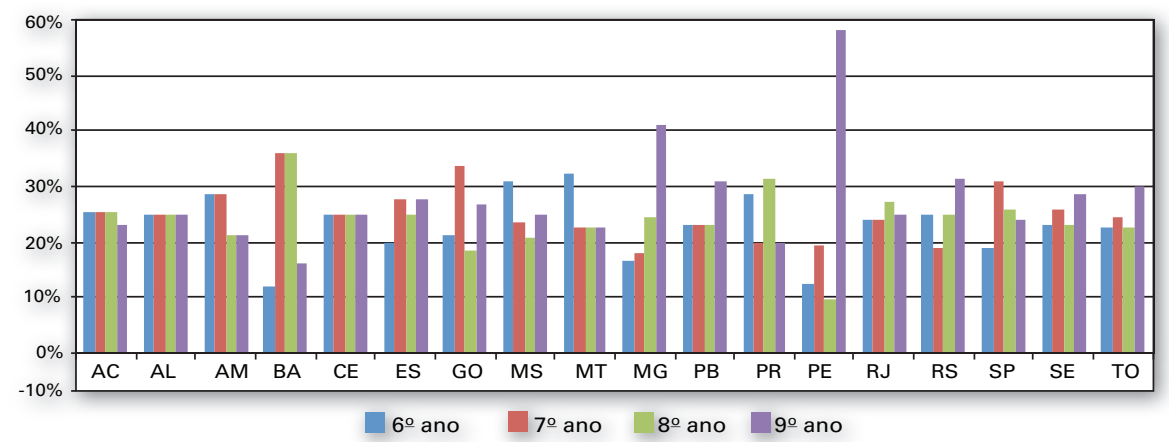

Observação: Para a adequada leitura do gráfico, conferir os comentários da Nota 5 sobre as propostas de Alagoas, Ceará e Amazonas, que explicam a homogeneização dos quantitativos referentes a cada ano. 
Encerrando este tópico, esclareçamos um pouco mais sobre a natureza das expectativas de aprendizagem ou, como circula na vulgata pedagógica, sobre o sentido de conteúdo nos currículos prescritos para a história. A literatura da área não chegou a um consenso sobre o que seria o específico em termos de aprendizagens históricas, ${ }^{10}$ razão pela qual consideramos os três tipos de 'conteúdo' correspondentes às posições em disputa: 1. habilidades específicas do ofício do historiador; 2. conhecimentos produzidos a partir das habilidades específicas do ofício do historiador; e 3. habilidades e conhecimentos que excedem às tarefas da heurística, análise, síntese e escrita históricas (ofício do historiador), demandadas, por exemplo, pela linguística, psicologia do desenvolvimento, psicologia da aprendizagem, filosofia (principalmente, a ética e a estética), política, sociologia e antropologia, ou seja, áreas do conhecimento que, geralmente, fundamentam as políticas educacionais para a escolarização básica.

Partindo dos saberes experienciais dos professores do ensino fundamental, poderíamos, sem grandes problemas, nomear o primeiro e o segundo tipo como objetivos específicos, e o terceiro como objetivos gerais. Eles serão detalhados no próximo tópico. Aqui, é bastante informar que $90 \%$ do total de objetivos são constituídos por habilidades e conhecimentos 'específicos' da história e apenas $9 \%$ enfocam outras áreas do saber. ${ }^{11}$ Examinado caso a caso, verificamos que 13 das 18 propostas possuem de $84 \%$ a $100 \%$ de objetivos voltados para as habilidades e conhecimentos específicos do ofício do historiador, demonstrando uma compreensão endógena e restrita a respeito dos 'conteúdos' concebidos como históricos.

As propostas da Paraíba e do Espírito Santo, por exemplo, são constituídas, respectivamente, por $71 \%$ e $65 \%$ de objetivos específicos, um pouco abaixo, portanto, da taxa majoritária. Esses dados significariam, então, que os dois desenhos curriculares reduzem o espaço do conhecimento histórico na formação dos adolescentes? É evidente que não. Conclusões desse tipo são possíveis somente após o levantamento em detalhe dos conhecimentos e habilidades explorados pelos objetivos. 
AS PRESCRIÇÕES EM TERMOS DE CONHECIMENTOS E DE HABILIDADES

\section{Conhecimentos e habilidades nos 'objetivos gerais'}

Comecemos pelos mais raros, os conhecimentos e habilidades constituintes dos objetivos que supostamente excederiam as tarefas clássicas do historiador. Eles somam 118 em um total de 1.380 objetivos. Além de serem minoritários em todas as propostas que os contemplam, eles não compõem os currículos de quatro estados (AM, BA, CE e PR). Porém, apresentam números significativos outros quatro: 47\% (SP), 35\% (ES, PB) e 23\% (MT).

As expectativas expressas por objetivos gerais abordam conhecimentos relativos à comunicação (39\%), ${ }^{12}$ quais sejam: leitura ${ }^{13}$ (sobretudo, busca de informações e interpretação de texto escrito) e escrita, análise e leitura de gráficos e tabelas e uso de mapas.

Os objetivos gerais também exploram temas relacionados aos valores que fundamentam o comportamento individual e a vida em sociedade (68\%). ${ }^{14}$ Nesse sentido, e em ordem decrescente de ocorrências, abordam cidadania, identidade, alteridade, diversidade cultural, étnica e de gênero, democracia, justiça, tolerância, solidariedade, direitos humanos, sociedade, o meio ambiente e o planeta. Esses objetivos também exploram a capacidade humana de transformação e de convivência da diversidade na unidade.

$\mathrm{Na}$ mesma rubrica, espera-se que os alunos ampliem as capacidades de viver em grupo, conviver com as ideias do outro, compreender e combater as ideias de dominação (entre os países), a atitude consumista, o preconceito e a discriminação em relação à mulher, aos idosos, aos afrodescendentes e aos indígenas. 
Gráfico 2 - Valores/atitudes x habilidades linguísticas por estado: Brasil (2007-2012)

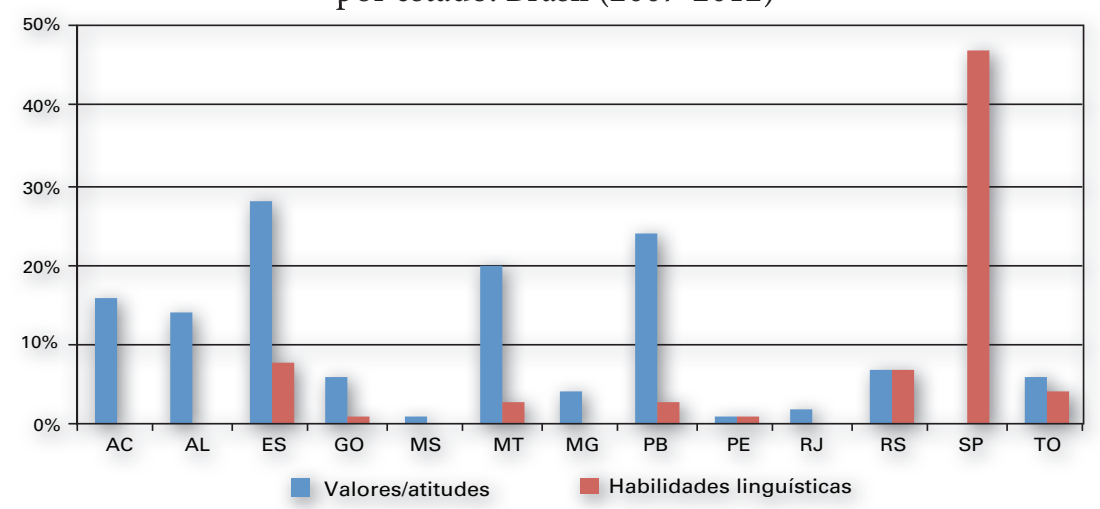

Observação: Os demais estados não apresentam expectativas em termos de valores/atitudes ou de habilidades linguísticas.

Em termos de habilidades, o 'aplicar' predomina nos objetivos de comunicação, coerente com a natureza da expectativa. Ao contrário, nos objetivos que abordam valores e atitudes, prevalecem as habilidades de baixa complexidade cognitiva - lembrar e compreender -, indicando maior ênfase na aquisição de informações em detrimento da resolução de situações-problema.

Este é o momento de retomar aquela indagação do tópico anterior, acerca da menor frequência de objetivos 'específicos' nas propostas do Espírito Santo, Mato Grosso e Paraíba e indicar que se trata de uma ressignificação dos conteúdos históricos e não, propriamente, de uma redução do espaço da história no currículo. Os valores e as atitudes, cidadãos em sua maioria, seriam absorvidos como tarefas da disciplina, tão importantes quanto a compreensão de acontecimentos do passado próximo ou distante.

No entanto, independentemente do desempenho desses e de outros estados, como demonstra o Gráfico 2, valores, atitudes e habilidades linguísticas representam aproximadamente $6 \%$ do total de expectativas no Brasil. Caso quiséssemos estabelecer um paralelo entre a tipologia empregada neste artigo e as possíveis razões que fundamentam a introdução dos objetivos gerais, ${ }^{15}$ sobretudo aqueles que abordam valores e atitudes, poderíamos afirmar, com convicção, que os princípios éticos, estéticos e de cidadania, seja na sua versão 
constitucional, seja na disposição indicada pela Unesco, ocupam um lugar restrito no currículo de história para os anos finais no Brasil.

\section{Conhecimentos e habilidades nos objetivos específicos: conteúdos meta-históricos}

Os objetivos 'específicos', como anunciamos no tópico anterior, são constituídos por habilidades singulares ao ofício do historiador (as operações processuais do ofício - pesquisa e escrita da história) e conhecimentos produzidos a partir do emprego dessas mesmas habilidades (são os 'fatos' ou os 'conteúdos propriamente ditos' da vulgata docente). Nomeamos os primeiros conteúdos como meta-históricos, e os últimos, como substantivos. Eles representam, respectivamente, $11 \%$ e $79 \%$ do total das expectativas prescritas. ${ }^{16}$

Gráfico 3 - Conteúdos substantivos x conteúdos meta-históricos: Brasil (2007-2012)

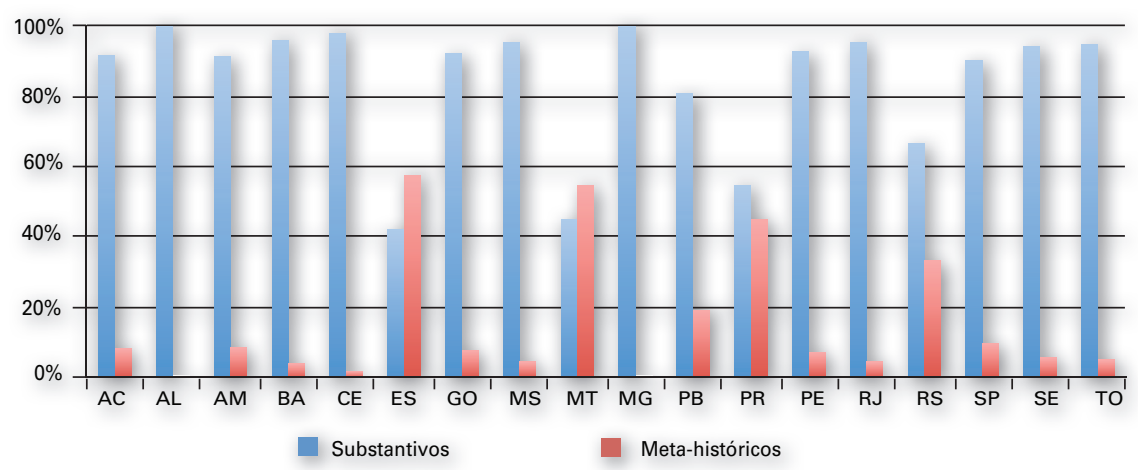

Como podemos acompanhar pelo Gráfico 3, apenas duas propostas não explicitam os conteúdos meta-históricos (AL e MG) entre os seus objetivos. Nas demais, entretanto, tais conteúdos são distribuídos de forma bastante variada. Há desenhos, por exemplo, que reservam pouco menos (PR - 45\%) ou pouco mais que a metade (ES - 58\%, MT - 55\%). Entretanto, há também propostas cujo espaço preenchido pelos conhecimentos e habilidades referentes à teoria da história, à pesquisa e à escrita histórica não ultrapassa os 5\% do total dos seus objetivos específicos (BA, CE, MS, RJ - 4\%, e TO - 5\%). 
Resta saber quais são os conhecimentos e habilidades mais recorrentemente utilizados pelas propostas. Esse exame é viabilizado mediante a recolha dos verbos e dos substantivos empregados no anúncio dos objetivos.

O Quadro 1 apresenta as escolhas de todas as propostas. Podemos observar as referências aos conceitos básicos (história-processo, história-ciência, fonte histórica, acontecimento, tempo, período, historicidade, sujeito histórico, duração, espaço, memória, narrativa, interpretação e anacronismo) e aos procedimentos canônicos que guiam a pesquisa e a escrita da história (observação, descrição, análise, comparação, interpretação, crítica e síntese) - ambos, objetos da formação inicial em história.

Tais escolhas, entretanto, não são expostas esquematicamente, como listamos acima - pelo menos, não o são nas propostas que apresentam baixo índice de conteúdos meta-históricos. Um estado, por exemplo, privilegia os conceitos de duração, fontes, interpretação-versão e a diferenciação história-ciência/história-vida (AC). Outro já concentra os objetivos na importância da história-ciência (BA). O terceiro espera do aluno a compreensão da ideia de historicidade e da diferença entre história e mito (SE). Um quarto estado, por fim, sugere os conhecimentos e as habilidades meta-históricas, apresentando o 'conteúdo' 'introdução à história' (CE) e assim por diante.

Mesmo nos estados que reservam maior espaço para os conteúdos meta-históricos, os objetivos são concentrados em quatro ou cinco noções e/ou procedimentos. Podem, por exemplo, privilegiar o trabalho com narrativas, fontes e na relação presente-passado (PR), com os conceitos de história, historicidade e memória e tempo e os procedimentos de observação, simultaneidade, mudança, permanência e ruptura, continuidade e descontinuidade (MT) ou, ainda, história, historicidade, tempo, narrativa e fontes (ES).

Verticalizando o exame sobre tais propostas, verificamos que os conteúdos meta-históricos são distribuídos nos anos finais de forma equilibrada em dois currículos (ES, MT). Apenas três propostas apresentam tendência decrescente, ou seja, maior quantidade de objetivos no sexto e menor no nono ano (TO, PB, PR), indicando possibilidade de progressão em termos quantitativos. ${ }^{17}$ 
Quadro 1 - Habilidades e conhecimentos meta-históricos: Brasil (2007-2012)

\begin{tabular}{ll}
\hline Habilidades & Conhecimentos \\
\hline Identificar & $\begin{array}{l}\text { Acontecimento (o conceito e o } \\
\text { referente) }\end{array}$ \\
Analisar & $\begin{array}{l}\text { Anacronismo (o conceito e o } \\
\text { referente) }\end{array}$ \\
Utilizar & Escalas (Cartografia) \\
Definir, reconhecer, reconhecer a & História-ciência (o conceito e o \\
importância e compreender & referente) \\
Discutir & Conceitos históricos \\
Comparar & Cronologias \\
Identificar & Durações \\
Analisar, comparar, compreender, & Fontes históricas \\
identificar, interpretar, ler, reconhecer, & \\
reconhecer a importância (para a escrita da & \\
história), utilizar, criticar e verificar & \\
Reconhecer, diferenciar & História conhecimento/história \\
& processo (vida) e história/mito \\
Relacionar & História individual e história \\
coletiva
\end{tabular}




\begin{tabular}{ll} 
Habilidades & Conhecimentos \\
\hline Conhecer & $\begin{array}{l}\text { Noções de tempo, espaço, duração } \\
\text { e periodização, temporalidade e } \\
\text { historicidade }\end{array}$ \\
& Pesquisa histórica \\
Estimular, projetar & Tempo (presente/passado) \\
Refletir & Procedimentos de observação, \\
Desenvolver & descrição, registro, comparação, \\
& análise e síntese \\
Problematizar, refletir & Sujeito histórico (conceito) \\
Conhecer, identificar, compreender, & Tempo \\
comparar representar (em linhas de & \\
tempo), medir & \\
Refletir & Valor do ensino de história
\end{tabular}

Outra informação relevante, mas que esse quadro não pode fornecer, é a frequência dos conhecimentos e das habilidades. De maneira geral (no somatório de todas as propostas), os conteúdos privilegiados são: fonte histórica, história-ciência e tempo. Esses três conceitos - isolados ou associados - preenchem mais da metade dos objetivos e estão presentes, respectivamente, em 11, 13 e 9 propostas, contabilizando 47, 26 e 14 ocorrências.

Quanto às habilidades, dos 27 verbos listados no Quadro 1, compreender, identificar, interpretar, comparar, conhecer e reconhecer concentram $50 \%$ das expectativas relativas aos conteúdos meta-históricos. Essa concentração revela um dado preocupante em relação aos procedimentos da pesquisa e da escrita da história: é diminuta a presença de habilidades de maior complexidade como analisar e diferenciar, e quase ausentes as iniciativas de avaliar (criticar/ julgar) e criar (hipóteses/generalizações/narrativas).

\section{Conhecimentos e habilidades nos objetivos 'específicos': conteúdos substantivos}

Independentemente do paradigma historiográfico de apoio, da orientação pedagógica em termos de aprendizagem e currículo, da maior ou menor proximidade com a legislação educacional produzida pelo estado, os conteúdos 
substantivos de história consideram, majoritariamente, o acontecimento como elemento central, ${ }^{18}$ tal como o define Paul Ricoeur. ${ }^{19}$ Nas 18 propostas em estudo, $87 \%$ dos objetivos tratam direta ou indiretamente dos acontecimentos. O restante das ocorrências remete diretamente aos protagonistas (4\%), artefatos (4\%) e aos conceitos (4\%). ${ }^{20}$ Vejamos, em, primeiro lugar, a categoria de maior frequência, ou seja, os conhecimentos e habilidades que exploram, na ausência de melhor palavra, a configuração ${ }^{21}$ dos acontecimentos.

Tabela 1 - Habilidades e conhecimentos

substantivos - configuração dos acontecimentos: Brasil (2007-2012)

\begin{tabular}{|c|c|}
\hline Habilidades ${ }^{*}$ & Conhecimentos ${ }^{*}$ \\
\hline $\begin{array}{l}\text { Compreender (10\%), identificar } \\
(8 \%) \text {, analisar }(6 \%) \text {, reconhecer } \\
(4 \%) \text {, refletir (3\%), relacionar }(2 \%) \text {, } \\
\text { discutir }(2 \%) \text {, comparar, descrever, } \\
\text { avaliar, caracterizar (1\%), imaginar, } \\
\text { valorizar (1\%), diferenciar, listar, } \\
\text { pesquisar, problematizar, ler, } \\
\text { refletir, escrever, definir, } \\
\text { posicionar-se, localizar, respeitar, } \\
\text { sintetizar. }\end{array}$ & $\begin{array}{l}\text { Consequências ( } 8 \%) \text {, semelhanças/ } \\
\text { diferenças (6\%), importância (5\%), } \\
\text { processo ( } 5 \%) \text {, causas ( } 5 \%) \text {, conceitos } \\
(4 \%) \text {, crescimento }(3 \%) \text {, mudanças (2\%), } \\
\text { estrutura (1\%), cronologia (1\%), história } \\
(1 \%) \text {, contexto (1\%), apogeu, } \\
\text { características, decadência, fim, limites, } \\
\text { permanências, representações, } \\
\text { crescimento, imaginário, importância e } \\
\text { origem. }\end{array}$ \\
\hline
\end{tabular}

* Os números relativos são extraídos da base de 1.118 objetivos que veiculam conteúdos substantivos. Os conhecimentos destituídos de porcentagem alcançaram menos de $1 \%$ desse total.

Como exposto na Tabela $1,{ }^{22}$ os conhecimentos auxiliam na identificação do acontecimento-chave, ou seja, exploram os seus constituintes, ciclo vital (início, desenvolvimento e fim), antecedentes e consequentes, a exemplo de: "Reconhecer as características da era imperialista: crescimento das cidades e a formação de um mercado e de uma cultura de massa" (AL, $9^{\circ}$ ano). Nesse exemplo, espera-se que o aluno 'reconheça' (habilidade) as 'características' (conhecimento) do 'imperialismo' (acontecimento-chave).

No entanto, ainda que o objetivo refira-se ao acontecimento 'imperialismo', ele não induz o aluno a reconhecê-lo de forma direta como neste outro exemplo: "Relacionar o Imperialismo com a Primeira Grande Guerra" (GO, 9o ano). Aqui, a habilidade 'relacionar' é imediatamente seguida do acontecimen- 
to 'Imperialismo'. Ambos, portanto, exploram o 'imperialismo', mas o primeiro objetivo o faz de forma analítica (dando a conhecer as partes) e o segundo de forma sintética (requerendo conhecimento prévio de 'imperialismo' para que o objetivo seja cumprido). ${ }^{23}$

Dentro dessa categoria, como podemos acompanhar pela Tabela 1, as causas, consequências e relevâncias ainda imperam, presentes, respectivamente, em 11, 13 e 10 propostas. No entanto, as velhas demandas da história dita conservadora convivem com expectativas de aprendizagem que exploram semelhanças e diferenças (14 propostas), processos (14), definições (11) e mudanças (10) nos eventos, bem acima, portanto, das tradicionais demandas por cronologia (8). Sobre as habilidades, constatamos o predomínio dos processos cognitivos mais simples: compreender (presente em 14 propostas), identificar (11), analisar (11), reconhecer (10). ${ }^{24}$

Tabela 2 - Habilidades e conhecimentos substantivos - os acontecimentos-chave: Brasil (2007-2012)

\begin{tabular}{|c|c|}
\hline Habilidades & Conhecimentos \\
\hline $\begin{array}{l}\text { Compreender (7\%), } \\
\text { identificar (7\%), } \\
\text { relacionar (3\%), } \\
\text { caracterizar, } \\
\text { analisar (3\%), } \\
\text { refletir, ler, escrever, } \\
\text { reconhecer (2\%), } \\
\text { comparar, discutir, } \\
\text { conhecer, definir, } \\
\text { descrever, } \\
\text { problematizar (1\%), } \\
\text { avaliar, diferenciar, } \\
\text { estimular, imaginar, } \\
\text { localizar (tempo/ } \\
\text { espaço), promover, } \\
\text { sintetizar, valorizar } \\
\text { e verificar. }\end{array}$ & $\begin{array}{l}\text { Acontecimentos - Abolição, abolicionismo, absolutismo, acordos } \\
\text { (Conferência de Berlim, Congresso de Viena, Aliados, Eixo, Pacto de } \\
\text { Varsóvia), Anistia, bandeiras, barroco, belle époque, capitalismo, } \\
\text { capitanias hereditárias, caudilhismo, código de desmembramento, } \\
\text { colônia, colonização (espanhola, europeia, francesa, inglesa, portuguesa), } \\
\text { Coluna Prestes, Confederação dos Tamoios, conquista/domínio (sobre os } \\
\text { territórios indígenas, do movimento Cartista, sertão, do campo sobre a } \\
\text { cidade, de Goiás, do Brasil, da América), Constituição de 1824, } \\
\text { contracultura, controle, propriedade/posse/uso da terra, coronelismo, } \\
\text { crise (de 1929, do século XIV), crescimento do Sudeste brasileiro, } \\
\text { cruzadas, democratização, depressão econômica, descobertas } \\
\text { (tecnológicas, arqueológicas), descolonização, desemprego, } \\
\text { desenvolvimentismo, despotismo esclarecido, Diretas Já, ditadura } \\
\text { (militar, Vargas), domesticação de plantas e animais, divisão social do } \\
\text { trabalho, dominação muçulmana, economia (do açúcar, café), emigração, } \\
\text { escravidão (antiga, moderna), centralização do poder, exclusão (social, } \\
\text { econômica), êxodo rural, família real/corte no Brasil, Fascismo, festivais } \\
\text { gastronômicos (GO), feudalismo, FICA (GO), Frente Negra Brasileira, } \\
\text { fundamentalismo, globalização, Golpe Militar de 1964, governo (Jânio }\end{array}$ \\
\hline
\end{tabular}




\begin{tabular}{|c|c|}
\hline Habilidades & Conhecimentos \\
\hline & $\begin{array}{l}\text { Quadros, João Goulart, militar, napoleônico, totalitário, Vargas), Guerra } \\
\text { (do Paraguai, Fria, local), Guerrilha do Araguaia, Igreja Católica } \\
\text { (combate à Reforma), Iluminismo, imigração, império (bizantino, } \\
\text { carolíngio), inconfidências, independência (da América espanhola, EUA, } \\
\text { América colonial, América francesa, América latina, Haiti), } \\
\text { industrialização, intervenção (dos EUA), islamismo/islão, liberalismo, } \\
\text { libertação nacional, lutas sociais, meio ambiente (preservação), } \\
\text { mercantilismo, modernismo, modernização (do estado, do país), } \\
\text { monarquia, movimentos (artísticos, culturais, de dominação, de } \\
\text { resistência, intelectuais, nativistas, políticos), nacional- } \\
\text { desenvolvimentismo, nacionalismo, nazifascismo, neoclassicismo, } \\
\text { neocolonialismo, oligarquia, Período 1930, perseguição à esquerda (no } \\
\text { Brasil, nos EUA), populismo, pós [segunda] guerra, pré-golpe militar, } \\
\text { Primeira (Guerra Mundial, República), Primeiro (Império, Reinado), } \\
\text { Proclamação da República, quilombos (resistência), redemocratização, } \\
\text { reforma (agrária, religiosa), Regência, regime (democrático, ditatorial, } \\
\text { militar, oligárquico), Renascimento (comercial, urbano), repressão, } \\
\text { República (oligárquica), resistência (de esquerda), revolta, Revolução (de } \\
\text { 1820, 1830, 1848, 1917, 1924, 1930, francesa, industrial, mexicana, russa, } \\
\text { socialista, soviética, política, cultural, inglesa, religiosa, social), Rússia } \\
\text { czarista, Segunda Guerra Mundial, Segundo (império, reinado), sistema } \\
\text { colonial, socialismo, stalinismo, tenentismo, terrorismo, tráfico } \\
\text { (indígena, negreiro), transição monarquia/república, Trombas (GO), } \\
\text { Formoso (GO), Tropicalismo e urbanização. }\end{array}$ \\
\hline
\end{tabular}

Na segunda posição, no que se refere à frequência, encontram-se as demandas por acontecimentos-chave. Eles ocupam $40 \%$ do total de expectativas. Como podemos observar pela Tabela $2,{ }^{25}$ tal categoria apresenta idêntica variação em termos de habilidade e maior dispersão em termos de conhecimentos.

As habilidades de compreender (presente em 13 propostas), identificar (10), caracterizar (9), relacionar, analisar (7) e reconhecer $(6)^{26}$ são as mais empregadas em termos de frequência relativa ao número total de objetivos como também em relação ao número de propostas que as adotam. Quando as comparamos com os dados da tabela anterior (Tabela 2), verificamos que, não obstante as pequenas variações de ordem e frequência, as expectativas referentes à configuração dos acontecimentos e aos próprios acontecimentos (acon- 
tecimento em detalhe/acontecimento em sua totalidade) apresentam habilidades idênticas e totais aproximados (25 habilidades para a 'configuração' e 24 para os 'acontecimentos').

Quanto aos acontecimentos, infelizmente, não podemos quantificar a frequência relativa ao total dos objetivos, uma vez que eles estão presentes em vários enunciados, de forma isolada ou relacionada. ${ }^{27}$ No entanto, é possível verificar que alguns deles constituem maioria absoluta das 18 propostas analisadas, sendo os mais recorrentes: guerra (presente em 14 propostas), revolução (14), república (12), cidadania (12), colonialismo, movimentos sociais (11), capitalismo, imperialismo (9). Além disso, considerada a presença das palavras política, economia, sociedade e cultura (com seus similares semânticos - político, econômico, social e cultural, socioeconômico e sociocultural), podemos afirmar que as dimensões mais conhecidas da topologia das capacidades humanas são referenciadas na maioria absoluta (algumas no total) das expectativas anunciadas pelas 18 propostas na seguinte proporção: social (126 citações e 18 propostas), cultural (99/18), político (90/17) e econômico (85/16).

Vejamos, por fim, a configuração das três categorias minoritárias também anunciadas como conteúdos substantivos: os artefatos, os conceitos e os protagonistas. Juntos, constituem apenas $12 \%$ do total de 1.118 objetivos.

Tabela 3 - Habilidades e conhecimentos

substantivos - protagonistas, artefatos e conceitos: Brasil (2007-2012)

\begin{tabular}{l|l}
\hline \multicolumn{1}{c|}{ Habilidades $^{*}$} & \multicolumn{1}{c}{ Conhecimentos $^{*}$} \\
\hline $\begin{array}{l}\text { Compreender (1\%), analisar, } \\
\text { avaliar, caracterizar, definir, } \\
\text { diferenciar, identificar, ler, } \\
\text { refletir, escrever, localizar, } \\
\text { reconhecer, refletir e verificar. }\end{array}$ & $\begin{array}{l}\text { Protagonistas - indígenas, asiáticos e africanos, } \\
\text { família real, classe social, trabalhadores da } \\
\text { mineração, intelectuais do iluminismo, massas } \\
\text { populares, mercado, capital, cidades e vilas, Belo } \\
\text { Horizonte, Goiânia, Egito, Mesopotâmia, EUA, } \\
\text { Europa. } \\
\text { Artefatos - códigos de leis, fontes, imagens, } \\
\text { patrimônio, propaganda, rotas e técnicas. } \\
\begin{array}{l}\text { I } \%), \text { avaliar, caracterizar, } \\
\text { compreender, conhecer, } \\
\text { descrever, discutir, listar, } \\
\text { reconhecer. }\end{array}\end{array}$ \\
\hline
\end{tabular}




\begin{tabular}{|c|c|}
\hline Habilidades* & Conhecimentos $^{*}$ \\
\hline $\begin{array}{l}\text { Identificar (1\%), compreender } \\
(1 \%) \text {, analisar (1\%), } \\
\text { caracterizar, comparar, } \\
\text { contextualizar, definir, } \\
\text { descrever, diferenciar, } \\
\text { discutir, reconhecer, refletir, } \\
\text { relacionar. }\end{array}$ & $\begin{array}{l}\text { Conceitos - cidadania, cidadão, classe, clientelismo, } \\
\text { coronelismo, democracia, divisão do trabalho, } \\
\text { escravidão, federalismo, feudalismo, mito, } \\
\text { monarquia dual, oligarquia, parlamentarismo, } \\
\text { patriarcado, populismo, relações sociais, trabalho } \\
\text { escravo, trabalho livre; doutrinas/ideologias/modelos } \\
\text { de pensamento - Monroe, do branqueamento, dos } \\
\text { movimentos políticos contemporâneos, do } \\
\text { movimento operário, religiosas, totalitárias e } \\
\text { iluministas; projetos - iluminista, universalista da } \\
\text { história moderna, imperialista napoleônico, político- } \\
\text { transformador, político-conservador, de ocupação e } \\
\text { construção da identidade, de ocupação da América } \\
\text { portuguesa. }\end{array}$ \\
\hline
\end{tabular}

* Os números relativos são extraídos da base de 1.118 objetivos que veiculam conteúdos substantivos. Os conhecimentos destituídos de porcentagem alcançaram menos de $1 \%$ desse total.

Pela Tabela 3, constatamos que a variação das habilidades é menor, quando comparadas às habilidades referentes às categorias já analisadas (configuração dos acontecimentos e demandas por acontecimentos-chave). Contudo, os atos de identificar, analisar e compreender continuam na lista dos mais requisitados, seja para o tratamento dos artefatos, seja para a abordagem dos protagonistas. Observe-se que os artefatos são assim considerados em razão de sua natureza inanimada. Os conceitos, por sua vez, dão sentido aos acontecimentos e aos objetos que encarnam vontades, regras, saberes e identidades. Conceitos e artefatos, entretanto, aparecem isolados ou relacionados a outros artefatos/acontecimentos, como nos respectivos exemplos: 1 . "Entender o que é ser cidadão no império" (RJ, $8^{\circ}$ ano); 2. "Analisar a Lei de Terras de 1850 e relacioná-la com a questão agrária no Império" (MG, $8^{\circ}$ ano).

Sobre os protagonistas (ou atores ou sujeitos históricos), é necessário alertar, mais uma vez, que listamos apenas os conteúdos substantivos anunciados imediatamente após as habilidades (também, de forma isolada ou relacionada). ${ }^{28}$ Eles são, principalmente, sujeitos individuais pessoais, coletividades, instituições jurídico-políticas, cidades, países e continentes considerados, alguns de forma metafórica, como detentores de vontade e promotores de ação. 
Protagonistas são categoria diminuta em frequência no total de objetivos. Isso ocorre, provavelmente, por causa do apelo ao coletivo, tendência crescente na historiografia dos últimos 20 anos.

Ampliando, porém, o universo de análise, incorporando os sujeitos individuais pessoais, por exemplo, mencionados nas categorias já comentadas, não será difícil constatar que tais protagonistas praticamente desapareceram dos currículos nas últimas duas décadas. Os tradicionais responsáveis pelas ações - os indivíduos, nomeados como pessoas - são tão raros que é possível listá-los aqui: D. João VI (RJ), D. Pedro II (PE), Napoleão Bonaparte (MS, PE), Abraham Lincoln (MG), Luís Carlos Prestes (AM, GO), Getúlio Vargas (AM, PE, MG, MX, GO, RJ, SP), Juscelino Kubitschek (MG), Jânio Quadros (MG) e João Goulart (MG). Ao que parece, perderam o status de objeto principal das expectativas de aprendizagem histórica, por exemplo, as figuras de Cabral, Camarão, Tiradentes, Isabel e Deodoro da Fonseca, entre os 'nacionais', e os irmãos Graco, Colombo e Henrique IV, por exemplo, entre os protagonistas da experiência estrangeira.

Outra constatação importante, mas que abrange todas as categorias de conteúdos analisados até aqui, foi a vigorosa referência aos novos sujeitos demandados na primeira década do século XXI. Eles estão presentes em 10\% do total das expectativas inventariadas. Africanos/afrodescendentes/África/cultura africana/cultura afro-brasileira e indígenas/cultura indígena são referenciados, respectivamente, por 11 e 10 propostas (entre 18). Essa proporção cai à metade quando o tema são as mulheres ( 5 propostas), e rareia em relação às crianças (2), jovens (2) e idosos (1).

O peso que o conjunto dessas temáticas representa no total de expectativas de cada proposta, porém, é bastante diversificado. Elas ocupam $28 \%$ (em 1 estado), 19\% (3), 14\% (1) 10\% (3), 9\% (1), 7\% (3), 6\% (1), 4\% (4), 3\% (2) e até $2 \%$ (1). Em $80 \%$ dos casos, os protagonistas frequentam as expectativas de forma isolada (ou indígenas ou mulheres ou crianças entre outras composições). Por isso, e pelo fato de as experiências indígenas, africana e afro-brasileira estarem presentes no currículo de história para os adolescentes há mais de um século (ainda que não tenham recebido a abordagem sugerida pela legislação atual), não nos é possível avançar nas afirmações sobre esse indicador. Apenas podemos inferir que a experiência de crianças, idosos e jovens representa uma inovação no currículo, típica do século atual. 
TEMPOS, DURAÇÕES, ESPAÇOS E ESCALAS

Considerando os acontecimentos em todas as expectativas, independentemente das categorias analisadas até agora, podemos examiná-las sob o ponto de vista do recorte do tempo, das durações, dos espaços focados e das escalas. Esses indicadores podem informar sobre o grau de permanência e/ou mudança em relação às periodizações e aos cenários privilegiados nas propostas da década de 1980 e início da de 1990. Eles também dão a conhecer os graus de incorporação de duas formas de abordar o tempo e o espaço que entraram para a historiografia brasileira (ao menos como sugestão) no mesmo período: os diálogos entre durações e os jogos de escala.

Em primeiro lugar, vejamos o tempo histórico, aqui viabilizado pelo artefato calendário. ${ }^{29}$ Seu domínio e sua representação no ensino de história foram bastante criticados na década passada, uma vez que a divisão quadripartite, entre outros problemas, não considerava experiências exteriores ao Velho Mundo. ${ }^{30}$ A nosso ver, não é o emprego da periodização clássica da experiência humana que aproxima ou distancia a proposta das prescrições inovadoras produzidas pelos especialistas e sim a distribuição de expectativas por períodos e a distribuição dos períodos por ano. O que temos, então, nas propostas do novo século?

Sobre o primeiro aspecto - expectativas por período -, os dados expressam maior preocupação por parte dos professores, técnicos e gestores com a experiência do contemporâneo ${ }^{31}(57 \%),{ }^{32}$ seguida de longe pelos acontecimentos das idades Moderna (18\%) e Antiga (6\%), da Pré-História (4\%), e do Medievo $(3 \%){ }^{33}$

Ao contrário do que ocorre com o emprego das habilidades, ${ }^{34}$ em termos de conhecimento a presença de vários conteúdos substantivos no mesmo objetivo é muito mais frequente. Dessa prática têm origem os objetivos compostos, ou seja, que incluem acontecimentos de dois ou mais períodos. Ainda assim, o emprego simultâneo das idades Moderna e Contemporânea é majoritário (7\%), superando os outros dois pares mais recorrentes que também incluem as duas idades dominantes - idades Antiga/Contemporânea (1\%) e Média/Moderna (1\%). ${ }^{35}$ 
Tabela 4 - Distribuição das expectativas de aprendizagem histórica por período e estado: Brasil (2007-2012)

\begin{tabular}{|c|c|c|c|c|c|c|c|}
\hline$\%$ & Atemporal & $\begin{array}{c}\text { Pré- } \\
\text {-histórico }\end{array}$ & $\begin{array}{c}\text { Pré- } \\
\text {-colombiano }\end{array}$ & Antigo & Medieval & Moderno & Contemporâneo \\
\hline $\mathrm{AC}$ & 60 & 2 & 3 & 1 & 3 & 20 & 9 \\
\hline $\mathrm{AL}$ & 7 & - & - & - & - & 4 & 89 \\
\hline AM & 34 & - & - & 9 & 3 & 18 & 36 \\
\hline BA & 4 & 4 & 4 & 8 & 12 & 28 & 40 \\
\hline $\mathrm{CE}$ & 6 & 2 & 2 & 2 & 1 & 18 & 70 \\
\hline ES & 100 & - & - & - & - & - & - \\
\hline GO & 27 & 1 & 2 & 5 & 1 & 22 & 43 \\
\hline MS & 16 & 6 & 1 & 18 & 1 & 12 & 46 \\
\hline MT & 93 & - & - & - & - & 3 & 5 \\
\hline MG & 11 & 4 & - & - & 2 & 18 & 65 \\
\hline $\mathrm{PB}$ & 38 & 8 & - & 4 & 1 & 12 & 37 \\
\hline PR & 77 & - & - & - & 4 & 11 & 7 \\
\hline $\mathrm{PE}$ & 14 & - & 3 & 4 & 3 & 19 & 58 \\
\hline RJ & 21 & 9 & - & 11 & 7 & 19 & 34 \\
\hline RS & - & - & 2 & 3 & 3 & 27 & 65 \\
\hline SP & 5 & 2 & 3 & 7 & 9 & 31 & 43 \\
\hline SE & 6 & 6 & 3 & 6 & 10 & 11 & 59 \\
\hline TO & 81 & 1 & 1 & - & 1 & 5 & 13 \\
\hline
\end{tabular}

Examinando a distribuição dos períodos em cada uma das propostas, observamos que os acontecimentos referentes ao período contemporâneo são majoritários em 12 das 18 propostas, o mesmo ocorrendo com o período moderno, situado em segundo lugar (em termos de frequência) em 17 currículos. A dominação do par moderno/contemporâneo só não se efetivou por completo porque seis estados optaram por elaborar objetivos que não prescrevem temporalidades, pondo ênfase nos conteúdos substantivos não datados (TO, AC) ou nos conteúdos meta-históricos (PR, MT), ou, ainda, distribuindo os objetivos quase que de forma equitativa entre as demandas substantivas, meta-históricas ou relacionadas aos valores da cidadania e da democracia (ES, PR). 
Mesmo entre aquelas propostas que dataram a maioria dos seus objetivos, chamaram a nossa atenção as propostas centradas no contemporâneo (AL), e que não explicitam a abordagem dos períodos pré-histórico (AM, PE, RS) e antigo (MG). Isso reforça ainda mais a hipótese de que a compreensão sobre a relevância do contemporâneo - bastante significativa no início da década de 1930 cresceu ainda mais nos currículos, ampliando de 40\%, na reforma Francisco Campos, ${ }^{36}$ para $57 \%$ nas reformas locais da primeira década do século XXI. ${ }^{37}$

Caminho inverso têm tomado os períodos antigo e medieval, reduzidos, respectivamente (e também em relação à reforma Francisco Campos) de 22\% e $13 \%$ para $3 \%$ e $6 \%$ nas atuais reformas. Os acontecimentos da pré-história (considerada a experiência americana - aqui categorizada de pré-colombiana) mantiveram sua representação no currículo. Outra mudança importante foi a introdução dos conteúdos sem referências temporais. ${ }^{38}$

Saber a frequência com que aparecem os períodos em cada proposta é importante, mas conhecer as formas de distribuí-los ao longo dos anos finais do ensino fundamental é ainda mais esclarecedor. Para tanto, comparamos as propostas aos dois perfis aqui citados: a distribuição total dos currículos no Brasil de 2012 e a clássica distribuição dos períodos na reforma Francisco Campos. Examinando a distribuição das expectativas atemporais, percebemos propostas que apresentam progressão decrescente (TO, PE, MG, GO) ou distribuição equânime para todos os anos (AL, AM, ES, MT, PB). Outras estão mais próximas das totalizações da reforma Campos (BA, CE, RJ, RS, SE), que apresenta (se não expectativas, mas) acontecimentos datados em sua totalidade.

Isso mesmo se pode dizer em relação ao contemporâneo. Das 18 propostas, 12 apresentam expectativas em progressão crescente (AC, BA, CE, GO, MS, MG, PB, PR, PE, SP, SE, TO), ou seja, quanto mais se avança para o último ano do ensino fundamental, mais se propõe o contemporâneo como tema para discussão. De igual maneira, em 12 das 18 propostas, o contemporâneo ocupa todos os anos letivos (AC, AL, AM, CE, GO, MS, MG, PB, PE, SE, TO). Esses números representam uma permanência em relação à reforma Campos, uma vez que 8 das 12 propostas que têm o contemporâneo como majoritário reservam o $9^{\circ}$ ano para as expectativas referentes a esse período. ${ }^{39}$

Desse exame, concluímos que não há modelo(s) dominante(s). Não se pode mais classificar os currículos prescritos de história como majoritariamente estruturados no quadripartidarismo (antigo, medieval, moderno e contem- 
porâneo). Porém, é cedo para se afirmar que os currículos contemporâneos integram os tempos e as temáticas de forma sofisticada, distante daquele modelo inaugurado pela reforma Campos. Isso só é possível conhecer por meio do exame da relação entre esses tempos, capturada mediante o diálogo das durações.

Gráfico 4 - Distribuição das durações nos anos finais do ensino fundamental: Brasil (2007-2012)

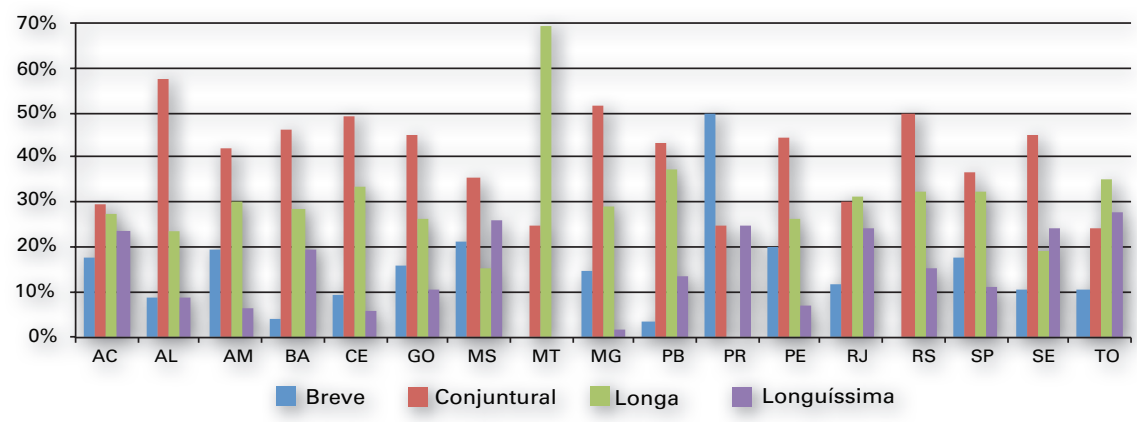

Como expresso no Gráfico 4, o tempo ${ }^{40}$ conjuntural ou a duração média dos acontecimentos predomina em 12 das 17 propostas. Em ordem decrescente, seguem-se a longa (MT, RJ, TO) e a breve (PR) duração. ${ }^{41}$ Observe-se que em duas propostas há concentração das durações longa (MT) e breve (PR).

Quando postas em comparação sob o ponto de vista da distribuição entre os anos finais do ensino fundamental, constatamos a predominância do tempo conjuntural no $7^{\circ}, 8^{\circ}$ e $9^{\circ}$ anos, seguido das durações longa, longuíssima e breve. Também constatamos que os tempos configuram uma progressão entre o $6^{\circ}$ e o $9^{\circ}$ anos, sendo crescente para o conjuntural e o breve e decrescente para os tempos longo e longuíssimo.

Quanto ao diálogo entre durações, isto é, a possibilidade de observar a experiência humana da perspectiva de uma ou mais de uma duração, enriquecendo, dessa forma a interpretação sobre um ou vários acontecimentos, os dados apontam para o exíguo emprego dessa estratégia (anunciada até mesmo pelos PCN). Do total de objetivos que informam sobre o tempo (996), apenas $4,3 \%$ (43) deles relacionam diferentes durações. ${ }^{42} \mathrm{O}$ pequeno grupo de objetivos com tempos compostos explora as durações breve e conjuntural (16 ocor- 
rências), breve e longa (8), conjuntural e longa (9), longa e longuíssima (9), e longuíssima e conjuntural (1).

Quadro 2 - Distribuição das expectativas segundo o espaço privilegiado nos anos finais do ensino fundamental: Brasil (2007-2012)

\begin{tabular}{|c|c|c|c|c|c|c|c|c|c|c|c|c|c|c|c|c|c|c|c|c|c|c|c|c|c|c|c|c|}
\hline & \multicolumn{7}{|c|}{$6^{\circ}$ ano } & \multicolumn{7}{|c|}{$7^{\circ}$ ano } & \multicolumn{7}{|c|}{$8^{\circ}$ ano } & \multicolumn{7}{|c|}{$9^{\circ}$ ano } \\
\hline & A & B & C & $\mathrm{D}$ & $\mathrm{E}$ & $\mathrm{F}$ & G & A & B & C & D & E & $\mathrm{F}$ & G & A & B & $\mathrm{C}$ & D & E & $\mathrm{F}$ & G & A & B & $\mathrm{C}$ & $\mathrm{D}$ & $\mathrm{E}$ & $\mathrm{F}$ & G \\
\hline AC & & & & & & & & & & & & & & & & & & & & & & & & & & & & \\
\hline AL & & & & & & & & & & & & & & & & & & & & & & & & & & & & \\
\hline $\mathrm{AM}$ & & & & & & & & & & & & & & & & & & & & & & & & & & & & \\
\hline BA & & & & & & & & & & & & & & & & & & & & & & & & & & & & \\
\hline $\mathrm{CE}$ & & & & & & & & & & & & & & & & & & & & & & & & & & & & \\
\hline $\mathrm{GO}$ & & & & & & & & & & & & & & & & & & & & & & & & & & & & \\
\hline MS & & & & & & & & & & & & & & & & & & & & & & & & & & & & \\
\hline MT & & & & & & & & & & & & & & & & & & & & & & & & & & & & \\
\hline MG & & & & & & & & & & & & & & & & & & & & & & & & & & & & \\
\hline $\mathrm{PB}$ & & & & & & & & & & & & & & & & & & & & & & & & & & & & \\
\hline $\mathrm{PR}$ & & & & & & & & & & & & & & & & & & & & & & & & & & & & \\
\hline $\mathrm{PE}$ & & & & & & & & & & & & & & & & & & & & & & & & & & & & \\
\hline RJ & & & & & & & & & & & & & & & & & & & & & & & & & & & & \\
\hline $\mathrm{RS}$ & & & & & & & & & & & & & & & & & & & & & & & & & & & & \\
\hline SP & & & & & & & & & & & & & & & & & & & & & & & & & & & & \\
\hline SE & & & & & & & & & & & & & & & & & & & & & & & & & & & & \\
\hline TO & & & & & & & & & & & & & & & & & & & & & & & & & & & & \\
\hline
\end{tabular}

Legenda: A - local; B - estadual; C - regional; D - nacional; E - continental; F - transcontinental; G - global. Observação: Este quadro indica apenas a presença ou ausência dos referidos espaços. Os dados foram contabilizados com base nas expectativas datadas.

No que diz respeito aos espaços de ação - cenários ou locus dos acontecimentos - os dados indicam exígua vantagem do espaço nacional-brasileiro (36\%) sobre o transcontinental (33\%), seguidos de longe pelos espaços global (13\%) e continental (11\%). A tríade estadual (5\%), regional (1\%) e local/municipal $(0,4 \%)$ apresenta a mais baixa frequência nas expectativas.

A distribuição desses espaços nos anos finais é bastante variável, não explicitando, portanto, um padrão. O local/municipal como cenário está presente, apenas, em uma proposta (GO), situado nos dois primeiros anos, ${ }^{43}$ enquanto o recorte estadual ocupa três ou mais de três anos em quatro propostas (GO, $\mathrm{MG}, \mathrm{MS}, \mathrm{TO})$ e um entre os dois anos finais em dois currículos (AC, TO). ${ }^{44}$ 
O reduzido número de expectativas que fazem referências ao regional ${ }^{45}$ (AM, GO, MG, MS, PE), por sua vez, explora a conquista e a ocupação e a formação de limites e fronteiras na Amazônia, no Centro-Oeste e no Sul, e a presença de indígenas no Centro-Oeste. Também abordam a urbanização do Nordeste e os processos de centralização administrativa e industrialização no Sudeste.

Quanto ao continental, ${ }^{46}$ dominantemente surge a experiência das Américas - do Norte, Central e do Sul - com metade dessa categoria, difusa em um, dois, três ou em todos os anos do ensino fundamental. Os movimentos de independência e a vivência dos povos pré-colombianos são conteúdos substantivos mais explorados, seguidos de acontecimentos da história moderna europeia.

Quando abordados dois ou mais continentes no mesmo objetivo, a situação se inverte: a Europa ocupa dois terços das representações, tratando, sobretudo, de guerras e revoluções e de movimentos como a Reforma e o Renascimento e a formação dos Estados nacionais. Em seguida, vem a América (com os temas já citados). A Ásia e a África estão parcamente representadas nessa e na categoria anterior.

O cenário global, dominado por temas como o capitalismo e seus constituintes - colonização, descolonização, globalização, entre outros -, está presente na maioria das propostas, no $6^{\circ}$ e no $9^{\circ}$ anos. E, por fim, vem o nacional-brasileiro, espaço majoritário nas propostas, distribuído pelos quatro anos, com maior presença no penúltimo, onde são explorados, com grande frequência, a economia do açúcar, a independência política, a transição monarquia/ república, o governo Vargas, a industrialização, o golpe de 1964/ditadura militar, a experiência indígena e a luta por cidadania.

A exemplo do que verificamos com as durações, os jogos de escala são pouco empregados nas propostas que anunciam objetivos com um ou mais cenários. Não chega a trinta o número de expectativas que sugerem o estabelecimento de relações entre dois ou mais espaços diferenciados. ${ }^{47}$ Assim, apesar de o espaço estadual ser bastante referenciado nas propostas, a explícita relação espaço estadual/espaço nacional é rara. ${ }^{48}$ As mais frequentes dão conta das interações entre espaço nacional e o americano ${ }^{49}$ e do espaço nacional e europeu. ${ }^{50}$ 


\section{Conclusões}

Ao final desta análise, podemos elaborar um perfil das expectativas de aprendizagem histórica para os anos finais do ensino fundamental, ambiente privilegiado de formação de pré-adolescentes e adolescentes e lugar de atuação do profissional com formação inicial em história.

Sobre o papel do ensino nesse processo de formação, vimos declinar a prática de orientar as propostas curriculares por uma teoria da história ou corrente ou escola. Mesmo quando definida a ciência da história, seu lugar na formação incorpora elementos da vulgata defendida por pesquisadores de vários países e recupera finalidades centenárias: formar identidades, cidadanias, compreender a realidade e os modos de produção do conhecimento histórico acadêmico.

A ideia de conteúdo é tributária do construtivismo (ou da aversão ao tecnicismo comportamentalista). As formas de nomeá-lo indicam pluralidade de concepções que vão do factualismo à história conceitual, do rígido controle à autonomia docente. Essa mesma variação pode ser observada quando se comparam as quantidades de expectativas por estado, encontrando-se desde indicações gerais até prescrições, por assim dizer, quase que diárias.

Em termos quantitativos, verificamos a ausência de progressão na maioria das propostas, a ênfase nos conhecimentos factuais e conceituais e procedimentais relacionados à pesquisa histórica, e a residual participação dos valores e conhecimentos linguísticos. Entre as expectativas que exploram os conteúdos meta-históricos, predominam as habilidades de baixa complexidade (conhecer, compreender) em detrimento das iniciativas de analisar e diferenciar. As habilidades de avaliar, criticar, elaborar hipóteses e narrar são raras. Das que empregam conhecimentos substantivos, também é patente o predomínio do 'conhecer' e do 'compreender', seja para explorar os acontecimentos como totalidade, seja para explorar os acontecimentos em sua configuração.

Ainda sobre os conhecimentos substantivos, pudemos verificar a presença equilibrada de todas as conhecidas e difundidas dimensões humanas, hierarquizadas em termos quantitativos na seguinte ordem: social, cultural, político e econômico. Sujeitos individuais pessoais são raros, e já se contempla a experiência de crianças, idosos e jovens. 
Quanto à incorporação de conceitos e abordagens recentemente introduzidos na historiografia de ponta, constatamos algumas assimetrias. $\mathrm{O}$ contemporâneo continua ampliando seu espaço no currículo e hoje já ocupa mais da metade do total de expectativas. Isso não significa, porém, apropriação das abordagens difundidas pela historiografia universitária. Trata-se de uma tendência verificada, por exemplo, desde a Reforma Francisco Campos, originada nas próprias demandas escolares. É provável que o contemporâneo só interrompa esse crescimento quando a historiografia didática assumir a rubrica do 'tempo presente' como um novo período da experiência humana.

Ainda sobre a incorporação da historiografia acadêmica, é certo afirmar que a duração conjuntural predomina e são verificados indícios de progressão entre o $6^{\circ}$ e o $9^{\circ}$ ano, no que diz respeito às durações longa e breve. No entanto, o diálogo entre durações tem uso restrito.

Isso mesmo podemos afirmar acerca dos jogos de escala. Apesar de bastante diversificadas em termos de recorte espacial - com ligeira vantagem do recorte nacional sobre o transcontinental -, as propostas que apresentam explícita relação entre o espaço estadual e o espaço nacional são raras. Frequentes são as interações entre Brasil e América e Brasil e Europa.

Como anunciamos no início, nosso objetivo foi traçar um perfil que subsidiasse as políticas públicas e apontasse algumas questões e temas prioritários para a pesquisa sobre ensino de história. Nesse sentido, encerramos este artigo convidando-os a refletir sobre as seguintes indagações:

1. Estaria o ensino de história nos anos finais do ensino fundamental incorporando finalidades, conhecimentos e habilidades das ciências humanas e sociais, independentemente das demandas da historiografia de ponta?

2. É possível reproduzir nas prescrições curriculares todas as inovações da pesquisa de ponta em termos de habilidades e de conhecimentos?

3. É possível atualizar a experiência crescente do tempo presente e manter os espaços ocupados pelos conhecimentos que explicam a construção do modo de vida ocidental (Grécia, Roma, Europa) e as heranças recentemente concebidas como formadoras de uma brasilidade (África)?

4. Devemos continuar mantendo a história local segregada ao ensino dos anos iniciais? 
5. As matrizes que fundamentam os instrumentos de avaliação nacional da aprendizagem em história, a exemplo do Exame Nacional do Ensino Médio, são representativas do conjunto das propostas curriculares em vigor?

6. A posição que o Brasil ocupa no cenário global (assim como as previsões sobre a manutenção e até o crescimento do seu papel) não sugeririam uma revisão desses currículos em termos de prioridades na seleção dos conhecimentos e das habilidades?

7. Após 25 anos de experiências curriculares, passando por dois grandes momentos na vida democrática - as lutas por extirpar os vestígios autoritários e as vitórias dos movimentos sociais -, não seria o momento de pensar numa base comum em termos de expectativas da aprendizagem ou, de maneira inversa, esperaremos que a disputa por cursos superiores (fundada na carência de vagas no setor público) transforme os itens de prova dos exames nacionais no currículo real para todos os brasileiros?

\section{FONTES}

ACRE. Governo do Estado. Cadernos de orientação curricular - Orientações curriculares para o ensino fundamental: Caderno 1 - História. Rio Branco: Acre, 2010.

ALAGOAS. Governo do Estado. Referencial curricular da educação básica para as escolas públicas de Alagoas. Maceió: Secretaria de Estado da Educação e do Esporte, 2010.

AMAZONAS. Governo do Estado. Proposta curricular do ensino fundamental do $6^{\circ}$ ao $9^{\circ}$ ano: Rede pública estadual. Manaus: Secretaria de Estado de Educação e Qualidade de Ensino, s.d.

ESPÍRITO SANTO. Governo do Estado. Currículo básico da escola estadual: guia de implementação. Vitória: Secretaria de Estado da Educação Básica e Profissional, 2009.

FORTALEZA. Prefeitura Municipal. Diretrizes curriculares para o ensino fundamental do sistema municipal de ensino de Fortaleza. Fortaleza: Secretaria Municipal de Educação, 2012.

GOIÁS, Governo do Estado. Reorientação curricular do $1^{\circ}$ ao $9^{\circ}$ ano. Currículo em debate: expectativas de aprendizagem - convite à reflexão e à ação. Goiânia: Secretaria de Estado da Educação, 2007.

MATO GROSSO DO SUL. Governo do Estado. [Proposta curricular para história nos anos finais do ensino fundamental]. Campo Grande: Secretaria de Estado da Educação, s.d. 
MATO GROSSO. Governo do Estado. Orientações curriculares da educação básica do estado de Mato Grosso. Cuiabá: Secretaria Estadual de Educação de Mato Grosso, [2010].

MINAS GERAIS. Governo do Estado. Proposta curricular de história do ensino fundamental: $6^{\circ}$ ao $9^{\circ}$ ano. Belo Horizonte: Secretaria de Estado da Educação, [2007].

PARAÍBA. Governo do Estado. Referenciais curriculares do ensino fundamental: ciências humanas, ensino religioso e diversidade sociocultural. João Pessoa: Secretaria de Educação e Cultura, 2010.

PARANÁ. Governo do Estado. Diretrizes curriculares da educação básica: História. Curitiba: Secretaria de Estado da Educação Básica, 2008.

PERNAMBUCO, Governo do Estado. Orientações teórico-metodológicas - ensino fundamental: História. Recife: Secretaria de Educação, 2011.

RIO DE JANEIRO. Governo do Estado. Currículo mínimo: História. Rio de Janeiro: Secretaria de Estado da Educação, 2011.

RIO GRANDE DO SUL. Governo do Estado. Lições do Rio Grande do Sul. Ciências Humanas e suas tecnologias. Caderno do Professor (ensino fundamental/ensino médio). Porto Alegre: Secretaria de Estado da Educação, [2009].

SANTOS, Cristiano dos; SILVA, Irlana Jane Menos da; SANTOS, Selma dos (Org.) Mentes e mãos construindo o Projeto Político Pedagógico (PPP). Feira de Santana (BA): Universidade Estadual de Feira de Santana, Departamento de Educação, Colegiados de Pedagogia, Fórum de Dirigentes das Escolas Públicas Estaduais, 2009.

SÃO PAULO. Governo do Estado. Proposta curricular do estado de São Paulo: História. São Paulo: Secretaria da Educação, 2008.

SERGIPE. Governo do Estado. Referencial curricular: rede estadual de ensino de Sergipe. Aracaju: Secretaria de Estado da Educação, 2012.

TOCANTINS. Governo do Estado. [Proposta curricular de História]. Palmas: Secretaria de Estado da Educação, [2009].

\section{NOTAS}

${ }^{1}$ BITTENCOURT, Circe Maria Fernandes. Propostas curriculares de História: continuidades e transformações. In: BARRETO, Elba Siqueira de Sá (Org.) Os currículos do ensino fundamental para as escolas brasileiras. 2.ed. São Paulo: Fundação Carlos Chagas; Campinas (SP): Ed. Associados, 2000. p.127-161. p.128.

${ }^{2}$ CARDOSO, Ciro Flamarion; VAINFAS, Ronald. Domínios da história: ensaios de teoria e metodologia. Rio de Janeiro: Campus, 1997. p.27-43.

${ }^{3}$ FREITAS, Itamar; OLIVEIRA, Margarida Maria Dias. Ensino de história nos currículos de história de doze municípios brasileiros: um perfil das habilidades e dos conhecimentos prescritos para a alfabetização histórica das crianças (2000/2010). Publicado em 27 mar. 2011. Disponível em: itamarfo.blogspot.com.br/2011/03/curriculos-de-historia-e-expectativas.html; FREITAS, Itamar. O que deve "saber" e "saber fazer" o profissional de História? 
Publicado em 2 abr. 2011. Disponível em: itamarfo.blogspot.com.br/2011/04/o-que-devesaber-e-saber-fazer-o.html.

${ }^{4}$ Este trabalho somente foi possível graças à colaboração de colegas pesquisadores de vários estados, aos quais somos enormemente agradecidos: Arnaldo Pinto Júnior (ES), Carlos Augusto Lima Ferreira (BA), Egberto Melo e Jane Semeão (CE), Jussara Luzia Leite (ES), Luciana Oliveira (BA), Magda Ricci (PA), Maria Augusta de Castilho (MS), Nathalia Alem (BA), Rita de Lourdes Campos Feitoza (RN), Simone Dias Cerqueira de Oliveira (BA) e Tarcisio Normando (AM).

${ }^{5} \mathrm{O}$ quadro que esboçamos aqui está condicionado à seguinte situação: 16 estados reformularam suas expectativas entre 2007 e 2012 - Acre, Alagoas, Amazonas, Espírito Santo, Goiás, Mato Grosso, Mato Grosso do Sul, Minas Gerais, Paraíba, Paraná, Pernambuco, Rio de Janeiro, Rio Grande do Sul, São Paulo, Sergipe e Tocantins; dois estados não prescrevem expectativas para os anos finais (é o município quem o faz), razão pela qual adotamos como amostra as propostas da capital ou de uma das diretorias regionais - Bahia e Ceará; quatro estados, além do Distrito Federal, estão reformulando ou construindo suas propostas (alguns até já as concluíram, mas ainda não disponibilizaram no site da Secretaria de Educação) - Pará, Rio Grande do Norte, Rondônia, Roraima; e um estado não será objeto de análise em virtude de a proposta ser datada de 1998 e, ainda, pelo fato de não apresentar expectativas de aprendizagem para os alunos - Santa Catarina. Apesar das buscas, até o fechamento deste artigo não obtivemos informações sobre as expectativas do Piauí e do Amapá. A proposta do Maranhão, que nos chegou após a conclusão do trabalho, será incluída em novo texto (em preparo) que examina as ideias de progressão e avaliação.

${ }^{6}$ Cf. ANDERSON, Lorin W.; KRATHWOL, David R. et al. A taxonomy for learning, teaching, and assessing: a revision of Bloom's taxonomy of educational objectives. New York: Longman, 2001.

${ }^{7}$ A proposta do Ceará anuncia conhecimentos. Os processos cognitivos são citados na exemplificação dos 'mapas de ensino'. A proposta de São Paulo indica processos cognitivos no texto introdutório. A informação objetiva sobre os 'conteúdos', entretanto, é também fornecida em termos de conhecimentos. A proposta do Rio Grande do Sul apresenta 'competências e habilidades' e 'sugestões de conteúdo'. Os conhecimentos substantivos estão presentes nos dois tópicos, mas somente 'competências e habilidades' constituem objetivos completos (verbos e substantivos).

${ }^{8}$ Apesar da variação em termos de quantidade de aulas semanais e dias letivos.

${ }^{9}$ A maioria das propostas discrimina as expectativas por ano, seguindo o ensino fundamental de 9 anos. As exceções são Alagoas, que aponta os objetivos ao final do $9^{\circ}$ ano, e Amazonas, que discrimina por biênios ( $6^{\circ}$ e $7^{\circ}$ anos e $8^{\circ}$ e $9^{\circ}$ anos). Os estados não adaptados ao ensino fundamental de 9 anos ou que fizeram a opção pelo trabalho com ciclos tiveram seus dados reclassificados para efeito de comparação. Foram os casos do Espírito Santo, Rio Grande do Sul (onde o $6^{\circ}, 7^{\circ}, 8^{\circ}$ e $9^{\circ}$ anos correspondem à $5^{\mathrm{a}}, 6^{\mathrm{a}}$, $7^{\mathrm{a}}$ e $8^{\mathrm{a}}$ séries) e do Mato Grosso ( $6^{\circ}$ ano corresponde ao segundo ciclo e $7^{\circ}, 8^{\circ}$ e $9^{\circ}$ anos correspondem ao terceiro ciclo). A proposta do Ceará (Fortaleza) apresenta os 'conteúdos' em bloco para o 
intervalo do $6^{\circ}$ ao $9^{\circ}$ ano. Para viabilizar as estimativas, distribuímos equitativamente os conteúdos da proposta do Ceará pelos quatro anos finais e repetimos as expectativas de Alagoas (do final do $9^{\circ}$ ano para os anos $6^{\circ}, 7^{\circ}$ e $8^{\circ}$ ) e do Amazonas (do biênio para os anos correspondentes).

${ }^{10} \mathrm{O}$ sentido de aprendizagem histórica e de conteúdos históricos está diretamente relacionado ao sentido de história-conhecimento, sobre o qual também não há consenso. Além desse condicionante, os interesses de pais de alunos (relativos aos exames e certificações), professores do ensino fundamental e professores universitários lotados em programas de pós-graduação, entre outros, se repartem nas defesas de um 'conteúdo histórico' mais ou menos factual (informação), centrado em conceitos das ciências humanas e sociais, ou nas habilidades e valores relativos ao ofício do historiador (que, às vezes, coincidem com os valores democráticos e de cidadania). Uma simples divisão encontrável nos textos de Peter Lee sintetiza e esclarece o sentido de conteúdo para aqueles que querem se iniciar na pesquisa. Ele afirma que a aprendizagem da história faz uso de dois tipos: os conhecimentos factuais (conceitos substantivos) e os conhecimentos da disciplina (conceitos de segunda ordem ou conceitos meta-históricos). Cf. LEE, Peter J. Putting principles into practice: understanding history. In: DONOVAN, M. Suzanne; BRANSFORD, John D. How students learn: history in the classroom. Washington: National Research Council of The National Academies, 2005. p.31-77. p.31.

${ }^{11}$ Os dados restantes (1\%) correspondem aos objetivos sobre os quais não foi possível estabelecer classificações (alguns, por má redação ou erros tipográficos).

${ }^{12}$ Embora não ofereça orientações específicas sobre o desenvolvimento dessa habilidade, a proposta de São Paulo é a mais fértil (considerada a possibilidade de os seus autores terem prescrito tais processos para todos os objetivos), representando dois terços do somatório dos objetivos de todos os estados que prescrevem habilidades linguísticas (ler e escrever).

${ }^{13}$ A leitura é entendida aqui, sobretudo, como busca de informações em textos escritos. Quando o objetivo determina que a busca seja feita em texto de documentos históricos e seus sinônimos (fontes, textos históricos etc.), classificamos a expectativa como meta-histórica e não, somente, como atividade de ampliação das habilidades linguísticas.

${ }^{14}$ A proposta da Paraíba nomeia esse tipo de objetivo como 'atitudinal' e 'procedimental'.

${ }^{15} \mathrm{Na}$ Constituição e na Lei de Diretrizes e Bases para a Educação Nacional podem ser observados os objetivos gerais nos princípios éticos (responsabilidade, solidariedade, respeito ao bem comum), de cidadania (exercício da criticidade, respeito à ordem democrática) e estéticos (sensibilidade, criatividade, diversidade de manifestações artísticas e culturais). Nas orientações da Unesco, os objetivos aqui rotulados como específicos correspondem ao 'saber' e ao 'saber fazer', enquanto os gerais estão relacionados ao 'saber ser, estar e comportar-se'.

${ }^{16}$ Os demais, como já afirmamos, correspondem aos objetivos gerais (9\%) e aos não identificados (1\%). 
${ }^{17}$ Afora esses casos, nenhuma proposta formula objetivos para todos os anos finais do ensino fundamental.

${ }^{18}$ Suponhamos a Revolução Francesa como exemplo. Certamente, as propostas que a incluem esperarão que os alunos apreendam o nome e os interesses dos sujeitos envolvidos, as causas, etapas, limites, consequências e importância da Revolução Francesa para determinado grupo, povo ou sociedade - não necessariamente contemplando todos os indicadores ou obedecendo a essa mesma ordem de exposição.

${ }^{19}$ Para Paul Ricoeur, o acontecimento em História corresponde ao que Aristóteles chamava de mutação de sorte - metabolé - na sua teoria formal da armação da intriga. Um acontecimento é o que não somente contribui para o desenvolvimento da intriga, mas dá a esta a forma dramática de uma mudança de sorte (Cf. RICOEUR, Paul. Tempo e narrativa. São Paulo: Papirus, 1994. v.1, p.320).

${ }^{20}$ Não foi possível chegar a uma classificação em $1 \%$ dos objetivos.

${ }^{21}$ Maneira pela qual as coisas se apresentam ou se desenvolvem (HOUAISS, Antonio. Dicionário eletrônico Houaiss da língua portuguesa 2.0. Rio de Janeiro: Instituto Antonio Houaiss; Objetiva, 2007. 1 CD-ROM).

${ }^{22}$ Os termos constituintes dessa e das próximas tabelas não esgotam o glossário das propostas. As palavras foram agrupadas e codificadas dentro do seu campo semântico para viabilizar a estatística, tanto dos conhecimentos (a exemplo de bases/estrutura/matrizes, causas/fatores/razões, expansão/crescimento/evolução/desenvolvimento, importância/influência/significado/legado/contribuição/papel/valor) quanto das habilidades (representar por desenho/desenhar, destacar o papel.../reconhecer, debater/discutir, distinguir/diferenciar, elencar/listar, entre outras).

${ }^{23}$ Pode parecer irrelevante essa sutil diferença. Mas, se mensurarmos as propostas estaduais de história ao longo do século XX, não será difícil concluir que migramos da expectativa direta para o exame do entorno e do interior, o que significa dizer, em termos pedagógicos, que estamos, gradativamente, substituindo a pergunta “o que é?" - inspiradora da memorização e da resposta ao pé da letra - para as questões “como é?" e "por que é?" - sugerindo, assim, a compreensão sobre o que se estuda. O mesmo se pode dizer em termos de teoria da história. Estamos mudando da história dita factual para a história problema.

${ }^{24}$ As pequenas variações de ordem de exposição, entre essa listagem e o descrito na Tabela 1, apenas confirmam a informação sobre a representatividade dessas habilidades, uma vez que os primeiros números (as porcentagens da tabela) são relativos ao total de objetivos, e os últimos (os algarismos entre parênteses) informam sobre a frequência das habilidades no total de propostas. Cruzando as duas informações, entretanto, é fácil concluir pela distribuição equilibrada de tal grupo de expectativas nas propostas brasileiras.

${ }^{25}$ Os números relativos são extraídos da base de 1.118 objetivos que veiculam conteúdos substantivos. Os conhecimentos destituídos de porcentagem alcançaram menos de $1 \%$ desse total. 
${ }^{26} \mathrm{O}$ conjunto 'refletir, ler e escrever', como já alertamos, apresenta-se em destaque, mas está concentrado na proposta de um estado, apenas: São Paulo.

${ }^{27}$ Como nos respectivos exemplos: "1. "Reconhecer no capitalismo financeiro os aspectos da concentração de capital pelas nações industrializadas e a expansão do capitalismo como a origem da internacionalização do capital e dos entraves do protecionismo" (PE, 9 ano); 2. "Relacionar a crise do socialismo e do capitalismo, nova expansão capitalista (globalização)" (PB, $9^{\circ}$ ano).

${ }^{28}$ Conforme os exemplos: 1. "Discutir o sertão como expressão de uma cultura" (GO, 7º ano); 2. "Identificar e caracterizar as instituições nacionais e internacionais que lutam pela garantia dos direitos dos cidadãos" (TO, 9 ano).

${ }^{29}$ RICOEUR, Paul. Tempo e narrativa. São Paulo: Papirus, 1997. v.3.

${ }^{30} \mathrm{Na}$ tabela a seguir, observem, isolamos os objetivos que abordam a experiência do Novo Mundo, anterior à colonização europeia, sob a rubrica de período pré-colombiano. Não queremos criar um novo período. É, apenas, um procedimento operatório para separar um tipo de acontecimento paralelo à experiência europeia e asiática, mas que não se enquadra na periodização quadripartite ou nas classificações que tomam por base os estágios tecnológicos comumente usados nos estudos de pré-história. Tentamos tratar com os mesmos critérios os acontecimentos relativos à história da África, mas a proposta mostrou-se inviável, dada a generalidade (ausência de referências sobre tempo e espaço no continente) com que os objetos abordam tal experiência.

${ }^{31}$ Aqui entendido como os acontecimentos referentes ao período iniciado a partir da Revolução Francesa.

${ }^{32}$ Números calculados sobre o total de expectativas datáveis, já que 32\% (474) dos 1.380 objetivos são atemporais (sobretudo aqueles relacionados aos conteúdos meta-históricos) ou genéricos (sem referências cronológicas, a exemplo das expectativas que abordam valores).

${ }^{33}$ Se somarmos os objetivos que tratam de povos pré-colombianos (2\%) aos da classe de pré-história, os acontecimentos relacionados ao período medieval aparentam representação ainda mais reduzida.

${ }^{34}$ Do total de expectativas que explicitam habilidades (111 não as explicitam), 86\% (1.094) são constituídas por um verbo, 12\% (155) por dois e 1\% (17) por três verbos. Há, também, dois casos com quatro verbos e apenas um com cinco. Neste trabalho, priorizamos o primeiro verbo de cada expectativa.

${ }^{35}$ Os conjuntos antiga/contemporânea, pré-colombiano/moderno, antiga/média, antiga/ moderna, média/contemporânea foram empregados, mas nenhum deles alcançou a frequência de $1 \%$.

${ }^{36}$ A proposta Francisco Campos destinava-se ao nível secundário e estruturava-se em cinco anos. No entanto, o público do secundário, em termos de faixa etária, é o mesmo dos anos finais do ensino fundamental (em média, a partir dos 10 anos de idade - na verdade, 
tratava-se de um curso pós-primário). Além disso, o secundário foi substituído pelo curso de primeiro grau (séries $5^{\mathrm{a}}, 6^{\mathrm{a}}, 7^{\mathrm{a}}$ e $8^{\mathrm{a}}$ ), que, por sua vez, ganhou o nome de ensino fundamental (anos finais). O elemento definidor da reforma Campos como termo de comparação, entretanto, está no seu caráter inaugural em termos de currículo: é a primeira proposta oficial, declaradamente integrada (Brasil/América/Mundo), como também o é a maioria das propostas contemporâneas.

${ }^{37}$ Esse fato talvez seja explicado pelo crescimento, na ausência de melhor termo, vegetativo dos acontecimentos contemporâneos e estabilização, também na ausência de melhor termo, dos acontecimentos da idade moderna que incluem a experiência brasileira.

${ }^{38}$ É provável que esse novo elemento, aliado ao crescimento vegetativo do contemporâneo, tenha causado essa drástica redução no espaço dos períodos antigo e medieval.

${ }^{39}$ Em relação aos períodos antigo e medieval, excetuando-se os estados que não os incluem (ES, MG, AL), apenas uma proposta (GO) não os distribui nos dois primeiros anos, aproximando-se, portanto, da disposição de 1931. O mesmo ocorre no que diz respeito às expectativas que tratam dos períodos pré-histórico e pré-colombiano. A maioria aproxima-se do modelo Francisco Campos (BA, CE, GO, MS, MG, PB, PE, SP, SE, TO), distribuindo-os ao longo dos primeiros anos, enquanto apenas uma proposta (RJ) prescreve o período pré-histórico para o $6^{\circ}$ e $9^{\circ}$ anos. As demais (AC, AL, AM, ES, MT, PR) não reservam, explicitamente, expectativas para o recorte pré-histórico.

${ }^{40}$ Estes foram os critérios de classificação das durações: tempo breve - 0 a 10 anos; duração conjuntural - 10 a 50 anos; longa duração - mais que 50 e até 300 anos; longuíssima duração - mais que 300 anos.

${ }^{41}$ As durações conjuntural e longa se equivalem na proposta do Acre. O currículo do Espírito Santo não permite o cálculo, já que as suas expectativas não prescrevem durações.

${ }^{42}$ Os que assim o fazem são, sobretudo, objetivos que exploram causas, consequências, significados, semelhanças e diferenças entre acontecimentos, como neste exemplo que pode reunir, respectivamente, as durações breve e conjuntural: "Compreender a Primeira Guerra Mundial como resultado das tensões territoriais-nacionalistas que marcaram a Europa entre o final do XIX e o início do XX, aliada às disputas por reservas de mercado características da segunda revolução industrial" (SE, $9^{\circ}$ ano).

43 "Identificar as origens das cidades goianas, seus nomes originais, sua arquitetura, festas e costumes" (GO, $7^{\circ}$ ano).

44 "Identificar e caracterizar a pré-história no Tocantins" (TO, 6 ano).

${ }^{45}$ Aqui entendido no sentido jurídico-político-administrativo mais recente, que divide o país em cinco territórios (Norte, Nordeste, Centro-Oeste, Sudeste e Sul).

${ }^{46} \mathrm{O}$ continente tomado isoladamente.

${ }^{47}$ A maioria das expectativas compostas (aproximadamente uma centena e meia) propõe o estabelecimento de relações do tipo "Brasil x Brasil" e "Europa x Europa".

48 "Identificar as consequências políticas do golpe militar (1964) em Goiás" (GO, 9ªno). 
49 "Relacionar o processo da abolição da escravidão nas áreas dos confederados com o processo de abolição no Brasil” (PE, 9ªno).

50 "Compreender as lutas socialistas e de libertação nacional contra a exploração e o domínio imperialista, bem como seus impactos na América Latina” (PB, 9ªno).

Artigo recebido em 20 de janeiro de 2012. Aprovado em 7 de maio de 2012 